\title{
PROSPEK PARIWISATA MOROTAI
}

\author{
Nurdin Natan \\ Dosen Universitas Pasifik Morotai \\ Email: nurdin.pasca@yahoo.com
}

\begin{abstract}
The development of tourism in a region into an object or area of tourism needs to pay attention to the potential of the area concerned in this case the District of Morotai Island, in order to create advantages that comparative in the area, that will be developed include the category still a novice compared to other regions which is much more advanced, with a competitive advantage that is difficult rivaled by other areas.

Tourism is the destination where tourists mencanegara maupu domestek melakuakan series of activities directly into one of the excellent for countries to improve their income sources outside of oil and gas and taxes. Currently Indonesia as a developing country in the field of tourism began to promote the country in order to attract the eyes of the world. Morotai is one area that has a sale value in the field of tourism related to him, the central government manjadikan Morotai as a regional tourist destination. Tourism destination is a series of activities carried out by foreign tourists and domestic that directly touch and involve the community so as to bring the economic impact on local communities.
\end{abstract}

Keywords : Morotai Tourism Prospects, Products, Productivity, Human Resources and Marketing

\section{PENDAHULAAN}

Pengembangan pariwisata merupakan salah satu bagian dari pembangunan ekonomi dalam rangka meningkatkan pertumbuhan ekonomi dalam suatu negara, sehingga dapat menciptakan lapangan kerja bagi masyarakat luas yang nantinya dapat meningkatkan pendapatan masyarakat secara keseluruhan pada akhirnya dapat meningkatkan kemakmuran masyarakat. Sasaran yang ingin dicapai dalam melakukan pengembangan pariwisata adalah untuk meningkatkan kunjungan wisatawan ke daerah yang akan dikembangkan, selain meningkatkan lama-nya waktu tinggal wisatawan. ${ }^{1}$

Pengembangan pariwisata dalam suatu daerah menjadi objek atau kawasan pariwisata perlu memperhatikan potensi yang dimiliki oleh daerah yang bersangkutan. Makin banyak potensi pariwisata yang ada dalam suatu daerah, makin layak daerah itu dikembangkan menjadi daerah tujuan wisata. Dimana potensi yang ada di suatu daerah dilihat dari aspek sosial, budaya, dan alam. Di samping memperhatikan potensi, perlu juga dalam pengembangan pariwisata di suatu daerah menciptakan keunggulan komparatif, apalagi daerah yang akan dikembangkan termasuk katagori masih pemula dibandingkan dengan daerah lain yang jauh lebih maju, yang memiliki keunggulan kompetitif yang sulit disaingi. Mengenai keunggulan komperatif yang perlu dikembangkan berupa potensi yang unik yang tidak dimiliki oleh daerah lain, sehingga mem- 
punyai daya tarik tersendiri yang dapat menarik wisatawan untuk mengunjunginya. Dengan demikian akan dapat tercipta efektivitas dalam pengembangan pariwisata yang sangat strategis. Untuk pengembangan pariwisata di suatu daerah tujuan wisata, perlu menentukan sarana dan prasarana apa yang perlu dilengkapi, agar tercipta pengembangan pariwisata efektif memenuhi kriteria.

Pariwisata menjadi salah satu primadona bagi negara-negara dalam meningkatkan sumber pendapatannya di luar dari migas dan pajak. Saat ini Indonesia sebagai salah satu negara berkembang mulai mempromosikan negaranya guna menarik pandangan mata dunia lain, hal ini dimaksudkan agar Indonesia semakin terkenal bagi warga atau penduduk negara lain untuk berkunjung ke Indonesia. Promosi-promosi yang dilakukan adalah menjual keragaman wisata dan budaya Indonesia, hal inilah ditanggapi positif dengan banyaknya wisatawan dari mancanegara yang berkunjung ke Indonesia. ${ }^{2}$ Indonesia yang memiliki keragaman budaya dan wisata melimpah itu mampu mengatasi masalah-masalah mendasar dengan penguatan ekonomi dari penerimaan devisa atau pendapatan daerahnya dengan itulah sebagai negara yang memiliki keragaman melimpah Indonesia dapat mengembangkan potensinya, misalnya dari segi pariwisata sebab wisatawan yang berkunjung ke Indonesia mencari atau menikmati keindahan pariwisata Indonesia sehingga memberikan efek domino bagi dalam maupun luar negeri, bilah dari luar negara kita semakin terkenal maka dalam negara kita dapat menambah devisa guna mengangkat kesejahteraan masyarakat yang ada saat ini.

Pariwisata memiliki peran yang besar dalam pembangunan nasional. Karena selain menghasilkan pendapatan dan sekaligus sebagai penghasil devisa, sektor pariwisata berkaitan erat dengan penanaman modal asing. Turis-turis yang datang ke Indonesia adalah termasuk mereka yang berhubungan bisnis dengan Indonesia.

Usaha pariwisata adalah kegiatan yang bertujuan menyelenggarakan jasa pariwisata atau menyediakan atau mengusahakan objek dan daya tarik wisata, usaha barang pariwisata dan usaha lain yang terkait dengan bidang tersebut. Industri pariwisata adalah suatu susunan organisasi, baik pemerintah maupun swasta, yang terkait dalam pengembangan, produksi dan pemasaran produk suatu layanan untuk memenuhi kebutuhan dari orang yang sedang berpergian.

Pariwisata di daerah-daerah sangatlah banyak bila mampu memanfaatkan potensipotensi yang ada, pemerintah dan masyarakat daerah saling membantu dalam pengembangannya tersebut sehingga akan mengangkat segi ekonomi, budaya, dan pendidikan daerah itu. Pariwisata sangatlah mampu dalam mengatasi masalah kesejahteraan bila dikembangkan secara profesional.

Pariwisata merupakan kegiatan yang kompleks, bersifat multi sektoral dan terfragmentasikan, karena itu koordinasi antar berbagai sektor terkait melalui proses perencanaan yang tepat sangat penting artinya. Perencanaan juga diharapkan dapat membantu tercapainya kesesuaian (match) antara ekspektasi pasar dengan produk wisata yang dikembangkan tanpa harus mengorbankan kepentingan masing-masing pihak.

Pariwisata sudah menjadi sebuah industri yang memberikan pengaruh pada aspek lain pada kehidupan. Pariwisata merupakan serangkaian kegiatan yang dilakukan wisatawan yang secara langsung 
menyentuh dan melibatkan masyarakat sehingga membawa berbagai dampak terhadap masyarakat setempat. Kegiatan kepariwisataan dilakukan mulai dari keberangkatan hingga di daerah tujuan di seluruh penjuru dunia. Dengan adanya aktivitas pariwisata ini dapat membuat masyarakat setempat mengalami siklus dalam kehidupannya, karena pariwisata dapat mendorong atau menyentuh berbagai aspek kehidupan masyarakat di sektor ekonomi maupun di sektor lain. ${ }^{3}$

Tulisan ini di maksudkan agar pembaca bisa menjadikan sebuah literatur dalam diskusi-diskusi yang di lakukan pada detlain waktu terkait dengan pangembangan pariwisata yang ada di indonesia khususnya di berbagai daerah yang kita ketahui bersama persoalan dengan destinasi wisata. Disemping itu penulis berharap terhadap pembaca agar dapat membrikan masukan terkait dengan perkembangan destinasi wisata yang ada di indonesia khususnya terdapat di daerah kita sendiri. Oleh karena itu fokus tulisan ini adalah bagamana peran pemerintah mengembangkan destinasi pariwisata yang ada di indonesia khususnya di daerah kita, bagamana peran aktif pemerintah daerah untuk meningkatakan fasilitas destinasi pariwiata yang ada di daerah dan sejaumana keterlibatan masarakat lokal sebagai tuan rumah terhadapa pengelolaan destinasi pariwisata.

\section{PEMBAHASAN}

Pengembangan pariwisata pada dasarnya merupakan pengembangan sarana dan prasarana pariwisata. Dalam menentukan sarana dan parasana yang perlu dibangun dalam rangka pengembangan pariwisata perlu memperhatikan sesuatu yang diinginkan wisatawan dalam melakukan perjalanan wisata ke suatu daerah tujuan wisata, di samping melihat potensi yang dimiliki oleh daerah tujuan wisata.

Pada umumnya ada 4 (empat) hal yang diinginkan oleh wisatawan, yang berupa Something to see (sesuatu yang dilihat), yang biasanya berhubungan dengan objek wisata dengan keindahannya dan atraksi budaya dengan keunikkannya; Something to do (sesuatu yang dapat dilakukan), yang biasanya berhubungan dengan penggunaan atau keterlibatan wisatawan dalam berbagai aktivitas pariwisata yang ketersediaan sarana pelengkap pariwisata yang berupa: kegiatan pesta kesenian dan budaya, kegiatan olahraga, tracking, cycling, jogging, climbing, horse riding, parasailing, hunting, dan sebagainya; Something to buy (sesuatu yang dapat dibeli), yang biasanya berhubungan dengan "sehingga" kata sambung intrakalimat tidak baik mengawali kalimat penyediaan sarana pendukung pariwisata, yang berupa gallery, artshop, dan kios seni dalam wadah pasar seni yang akan menawarkan produk pariwisata.

Produk wisata yang ditawarkan lebih banyak bercirikan produk lokal yang menjadi ikon daerah pariwisata yang bersangkutan; Service (pelayanan), yang berhubungan dengan

pelayanan yang diberikan oleh pelaku industri pariwisata. Namun yang terpenting adanya keramahtamahan dari Masyarakat daerah tujuan wisata dan adanya sikap yang mudah menerima wisatawan yang menyebabkan timbulnya rasa nyaman bagi wisatawan untuk berinteraksi dengan Masyarakat setempat. Jika daerah tujuan wisata memiliki dan bisa memberikan serta menyediakan keempat keinginan wisatawan tersebut, maka akan dapat meningkatkan kunjungan wisata ke daerah tujuan wisata tersebut, selain akan dapat memperpajang lamanya tinggal wisatawan di daerah 
tersebut. $^{4}$

Berdasarkan análisis potensi, kondisi, dan eksistensi kawasan pariwisata. Maka dalam pengembangan pariwisata ada beberapa alternatif sarana dan prasarana pariwisata yang perlu dibangun dan diperbaiki, yaitu:

\section{Memperbaiki dan Membangun Sarana Utama Pariwisata:}

a. Memperbaiki desain dan manajemen hotel. Perlu adanya perbaikan desain hotel yang berkarakter budaya lokal dengan sentuhan desain modern. Sedangkan untuk perbaikan manajemen dengan membangun jaringan bisnis pariwisata disamping memperbaiki manajemen operasional dan pemasarannya.

b. Membangun panggung atraksi budaya. Atraksi budaya merupakan produk wisata yang mempunyai nilai seni yang perlu ditawarkan kepada wisatawan. Di mana di daerah kita mempunyai keragaman seni budaya, sehingga perlu adanya pementasan karya seni budaya masyarakat yang perlu dibangun. Dalam operasinya perlu adanya penerapan manajemen skedul pementasan yang efektif

c. Perlu adanya pembangunan dan penataan wisata kuliner. Supaya memberikan kesan yang menarik untuk tempat melakukan lunch maupun dinner bagi wisatawan. Disamping itu bisa menyajikan menu makanan dan minuman yang dapat menggoyang lidah wisatawan

d. Memperbaiki manajemen objek wisata. Untuk mempercantik obyek wisata yang dikunjungi perlu adanya penataan lingkungan yang ada di areal objek maupun dijalur menuju obyek wisata. Sehingga dapat memberikan keindahan yang menarik untuk dikunjungi. Sedangkan dalam operasinya perlu adanya proses manajemen yang dapat memberikan kepuasan bagi wisatawan terutama dapat meminimalkan complain dari wisatawan.

\section{Memperbaiki dan Membangun Sarana Pelengkap Pariwisata.}

Sarana pelengkap pariwisata merupakan produk wisata yang dapat memenuhi Something to do (sesuatu yang dapat dibeli) bagi wisatawan di daerah tujuan wisata, sehingga daerah tujuan wisata akan lebih menarik bagi wisatawan untuk dikunjungi, di samping berfungsi memperpanjang lamanya tinggal di daerah tujuan wisata. Dengan demikian akan memberikan keuntungan bagi pelaku bisnis pariwisata, masyarakat, dan pemerintah. Berdasarkan analisis potensi, kondisi, dan eksistensi, maka sarana pelengkap pariwisata yang perlu dikembangkan dan diperbaiki meliputi:

a. Membangun sarana jogging dan cycling. Kegiatan jogging dan cycling merupakan kegiatan yang murah meriah, sehingga pasarnya sangat besar sekali, tidak hanya wisatawan asing, tetapi juga bisa dijangkau oleh wisatawan domestik maupun lokal. Sehingga sangat memungkinkan dapat meningkatkan jumlah kunjungan yang sangat signifikan ke objek wisata. Untuk itu sangat efektif 
untuk membangun sarana jogging yang bisa juga sebagai jalur cycling (tempat bersepada).

b. Membangun lintasan wisata berkuda Sarana pariwisata ini sangat cocok di bangun di Kabupaten Pulau Moratai perbukitan yang memberikan kesan menantang dan sekaligus dapat memberikan kesempatan bagi wisatawan untuk menikmati panorama lembah dan puncak pegunungan yang sangat eksotis. Apalagi produk wisata ini belum ada di daerah lain yang mengembangkannya, sehingga produk wisata ini mempunyai keunggulan komparatif yang ada kecenderungannya mempunyai nilai jual yang tinggi. Oleh karena itu, perlu membangun lintasan wisata berkuda yang mengelilingi kaki gunung Morota. Apalagi didukung dengan manajemen yang professional, maka akan dapat membangun citra favorit bagi kawasan wisata Kabupaten pulau Moratai sebagai pariwisata berkuda yang sangat strategis.

c. Menyediakan sarana dan prasarana wisata tirta. Kawasan wisata pulau dodola, tanjung gorango dan panati Sopi sangat petensial dikembangkan menjadi wisata tirta yang berupa atraksi wisata yang meliputi: para sailing, banana boat, ski air, dan sebagainya. Oleh karena itu perlu disediakan sarana dan prasarananya.
3. Membangun Sarana Pendukung. Sarana pendukung juga merupakan produk wisata yang fungsinya untuk memenuhi something to buy bagi wisatawan. Nampaknya di kawasan pariwisata belum ada beroperasi gallery yang menjual cindramata dan jenis kerajinan lainnya dan memasuki obyek wisata nampaknya belum ada gallery dan artshop yang beroperasi. Untuk itu, maka dalam pengembangan pariwisata yang berbasis kerakyatan sangat perlu membangun pasar seni sebagai sarana pendukung pariwisata di area obyek wisata yang akan dijadikan lokasi proyek pengembangan pariwisata.

\section{Memperbaiki dan Membangun Prasarana Pariwisata.}

Prasarana pariwisata merupakan asesibilitas bagi perkembangan pariwisata yang berupa: jalan, listrik, air, rumah sakit, telepon dan lainnya yang juga merupakan prasarana umum bagi semua masyarakat. Asesibiltas yang ada di kawasan wisata sudah tersedia namun belum memadai untuk pengembangan pariwisata, terutama telpon dan rumah sakit/puskesmas yang ada di area obyek wisata. Untuk itu, maka perlu diperbaiki, bahkan perlu di bangun fasilitas tersebut. Disamping itu perlu menciptakan kondisi yang nyama para pengunjung agar aman bagi perkembangan pariwisata kedepannya. 


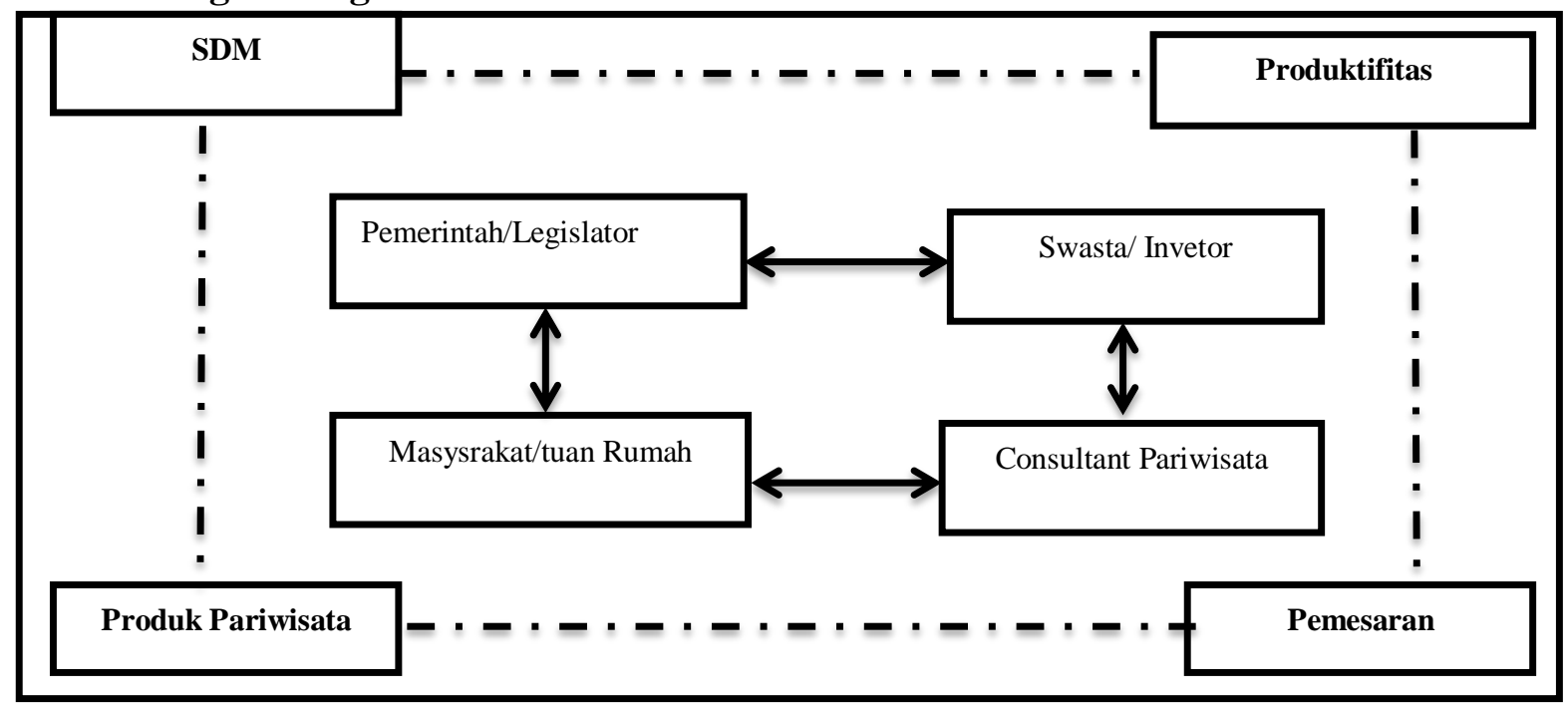

Gambar: 1. Model Pengembangan Pariwisata

Pemangku Kepentingan Dalam Pengembangan Pariwisata

Sumber: Wearing (2001) di modifikasi oleh Nurdin Natan (2016)

Gambar 1 menunjukkan sinergi berbagai komponen bisnis dalam mencapai tujuan yang diharapkan dalam pengembangan destinasi pariwisata sangat diperlukan strategi antara lembaga-lembaga terkait yang ada di daerah, terutama strategi pengelolaan dan strategi pemasaran. Di mana strategi pengelolaan yang perlu diterapkan, meliputi: ${ }^{5}$

\section{Strategi Pengelolaan \\ Pemasaran.}

dan

Menerapkan manajemen terbuka antara pelaku pariwisata dengan pengambil kebijakan (pemerintah) dan dengan masyarakat dalam rangka menciptakan keadilan, sehingga akan dapat menciptakan stabilitas bagi pengembangan pariwisata, ${ }^{6}$ Menciptakan sistem keamanan terpadu antara aparat, hansip, pecalang, dan masyarakat dalam rangka memberikan rasa aman dan nyaman bagi wisatawan yang dapat meningkatkan popularitas kawasan wisata, Perlu menerapkan konsep profesionalisme dalam pengelolaan sarana pariwisata dalam memberikan pelayanan agar dapat memuas- kan para wisatawan yang telah menikmati sarana pariwisata, Perlu membuat counter tourist information centre (TIC) terutama memberikan informasi kepada wisatawan terutama kepada wisatawan petualang, Prioritaskan tenaga kerja lokal yang mempunyai kemampuan, tetapi jangan mengabaikan konsep profesionalisme. Strategi pemasaran yang perlu diterapkan dalam pengembangan pariwisata di kawasan gunung.

Membuat desain produk wisata yang unik dengan memperhatikan local genius dalam rangka menciptakan kunggulan komperatif, Manfaatkan masyarakat lokal yang bekerja di luar untuk ikut memasarkan kawasan pariwisata daerah beserta sarana dan prasarananya, Tetapkan harga yang bersaing dengan daerah lain dan berlakukan promosi penjualan dengan memberikan pelayanan tambahan, Melakukan kerja sama dengan travel agent, guide, dan para driver secara intensif dengan kontrak bisnis, Melakukan promosi secara intensif melalui berbagai media promosi (brosur, majalah, dan lewat dunia maya), melakukan promosi langsung ke negara yang 
potensial, serta perlu kerjasama dengan travel asing baik yang sudah beroperasi didaerahmaupun yang ada di luar negeri.

Meningkatkan pelayanan dalam rangka menciptakan repeater tourist (datang berulang kali) dan sekaligus berfungsi sebagai promosi yang bersifat walk of mouth (promosi dari mulut ke mulut) yang sangat efektif dalam meningkatkan kunjungan.

\section{Produktifitas Pariwisata}

Produktifitas tidak akan meningkat jikalau pemerintah daerah (Kabupaten Pulau Morotai) tidak sinergi antara dinas terkait dalam ahal ini SKPD yang saling berkaitan dengan program kepariwisataan, akan tetapi untuk lebih baik keterlibatan masyarakat dan swasta. Tingkat produktifitas parawisata Morotai bisa di lihat dalam tebe 1 (satu) di bawa ini yang menunjukan bahwa masi rendah tingkat produktifitas pariwisata yang ada di Morotai.

Tabel 1 : Kunjungan Wisatawan Domestik dan Mancanegara 2011-2013

\begin{tabular}{|l|l|l|l|l|l|l|}
\hline \multirow{2}{*}{ Wisatawan } & 2011 & & 2012 & 2013 & \\
\cline { 2 - 6 } & Jumlah & $\%$ & Jumlah & $\%$ & Jumlah & $\%$ \\
\hline Domestik & 300 & 71,4 & 5.940 & 96,6 & 500 & 70,0 \\
\hline Mancanegara & 120 & 28,6 & 500 & 3,4 & 300 & 30,0 \\
\hline Jumlah & 420 & 100 & 6.149 & 100 & 800 & 100 \\
\hline
\end{tabular}

Sumber : LAKIP Disparbud Kababupaten Pulau Morotai

\section{Produk Pariwisata Morotai.}

Morotai memiliki produk pariwisata yang sangat melimpah di antaranya adalah pulau dodolah, pulau sum-sum, tanjung gorango, pamatai sopi sebagai tempat selancara, air terjun raja, air terjun berebere Moratai Utara, air terjun Nakamura di SP II dan tempat-tempat sejarah perang dunia kedua diantaranya makam serdadu perang dunia kedua serta Tank Amphibi. Morotai juga memiliki tarian adat di antaranya adalah tarian cakalele, tide-tide dan tarian tokuwelah, jikalau produkproduk destinasi periwisata Morotai di kelolah secara maksimala oleh pemerintah dearah (Kabupaten Pulau Morotai) maka akan meningkatkan pendapatan Masyarakat serta pendapatan asli daerah (PAD) Kabupaten Pulau Morotai.

\section{Pembangunan Destinasi Wisata}

Pembangunan destinasi pariwisata area wisata kiranya sangat penting karena akan memberikan kepuasan tersendiri para pengunjung. Oleh karena itu Pemerintah harus menyediakan fasilitas yang ada di destinasi Pariwisata. Fasilitas yang di sediakan di antaranya adalah sebagai berikut:

a. Fasilitas akomodasi yang tersedia yang memadai, terutama klasifikasi hotel tergolong hotel melati dengan fasilitas dan pelayanan yang sederhana.

b. Fasilitas dan pelayanan rumah makan/restoran yang sederhana.

c. Transportasi laut/boat untuk fasilitas mengunjungi kawasan wisata dan pemandu wisata untuk memberikan informasi terkait dengan kawasan wisata.

d. Transportasi darat dan biro perjalanan wisata. $^{8}$ 


\section{Sumber Daya Manusia}

Pariwisata merupakan industri jasa (services industry) industri kemarahtamahan (hospitality industry) dan industri citra/kesan (image industry), maka peranan kualitas sumber daya manusia sangat penting agar mampu memberikan kepuasan kepada wisatawan baik dalam bentuk pelayanan pada industri pariwisata maupun sikap masyarakat lokal (host) yang ada di daerah tujuan wisata.

Pimpinan organisasi semakin menyadari bahawa karyawan baru pada umumnya hanya mempunyai kecakapan teoritis saja dari bangku kulain, jadi, perlu dikembangkan dalam kemampuan nyata untuk dapat menyelesaikan pekerjaannya. Pengembangan karyawan (baru/lama) perlu dilakukan secara terencana dan berkesinambungan. Adapun tujuan pengembangan sumber daya manusia hakikatnya menyang-kut hal-hal berikut:

a. Produktifitas. Kerja melalui pengembangan sumber daya manusia, kualitas dan kuantitas produksi semakin baik. Karena kemampuan teknis, keahlian manusiawi dan kemampuan manajerial juga semakin baik maka produktifitas kerja meningkat.

b. Efesiensi. Pengembangan sumber daya manusia dapat menghemat sumber daya, tenaga, waktu, dan faktor-faktor produksi karena dapat mencari dan mengurangi terjadinya kesalahan-kesalahan, sehingga biaya produksi relatif kecil.

c. Karir. Dengan pengembangan, kemampuan karyawan untuk meningkatkan karir semakin besar karena keahlian, keterampilan, dan prestasi kerjanya sudah lebih baik. d. Kepemimpinan. Dengan pengembangan kepemimpinan, seorang manajer akan lebih baik karena kemampuan dan keterampilan yang dimilikinya, untuk memaksimakan pengembangan organisasi yang ai pimpin selama menjabatnya.

\section{Consultsnt Pariwisata}

Maorotai adalah salah satu daerah yang memngembangkan destinasi pariwisata, akan tertapi dengan keterbatasan sumber daya manusia (SDM) khusunya keterbatasan SDM pariwisata sehingga pengelolaannya belum maksimal sehingga masi jauh dari kepuasan pengujung destinasi wisata da demi kemanfaatan ekonomi pariwisata terhadap peningkatan pendapatan Asli daerah (PAD) dan kesejhateraan Masyarakat, maka pemerintah daerah tidak perlu segan-segan melibatkan Consultat pariwisata yang profesonal dan pengalaman dalam menyelesaikan permasalahan-permasalahan terkait dengan pengembangan destinasi pariwisata Morotai.

\section{Pemerintah/Legislator}

Dalam pengembangan destinasi pariwiwsata yang berkelamjutan di perlukan keikhlasan Pemerintah daerah menentukan layak tidaknya produk wisata yang akan dikembangkan, oleh karena itu pemerintah perlu kiranya dapat mengkaji dari beberapa aspek yaitu: ${ }^{9}$

a. Keberpihakan aspek politikhukum. Pengembangan pariwisata perlu adanya dukungan yang sifatnya politik baik dari pemerintah maupun dari masyarakat, dan yang terpenting adanya motivasi pelaku bisnis pariwisata untuk berinvestasi di daerah 
tujuan wisata tersebut. Di samping perlu adanya peraturan daerah yang dapat menjadi payung operasional dalam menjaga stabilitas perkembangan pariwisata. Dari aspek ini juga perlu adanya sistem keamanan kawasan dari berbagai tindak kriminal dan dari konflik sosial yang sangat mengganggu stabilitas pariwisata.

b. Keberlanjutan aspek finansial. Pengembangan pariwisata sangat diperlukan adanya dukungan dana untuk membangun sarana dan prasana pariwisata serta dana untuk pengelolaannya. Untuk menentukan kelayakan proyek pengembangan ini dari aspek finansial, dapat dilihat dari prospek proyek ini dalam meningkatkan kunjungan wisatawan dan benefit cost ratio dari proyek ini dalam operasional yang sesuai dengan umur ekonomis proyek ini. Kalau dilihat dari prospek, di mana program pengembangan proyek ini sangat propektif, melihat perkembangan pariwisata yang mengunjungi kawasan pariwisata dari tahun-ketahun, sehingga ada kecendrungan dengan adanya penawaran produk wisata yang berbasis budaya dan kuliner pada obyek wisata, sehingga dapat meningkatkan penjualan dari para pelaku bisnis pariwisata

c. Keberlanjutan aspek ekonomi. Pariwisata merupakan industri yang bersifat "labor Intensive" yang merupakan sektor ekonomi yang banyak menyerap tenaga kerja dibandingkan dengan sektor ekonomi lainnya termasuk sektor pertanian dalam arti luas, sehingga mampu menyediakan lapangan kerja yang lebih luas yang dapat membantu pemerintah mengurangi pengangguran yang sifatnya lokal maupun nasional, sehingga dengan dikembangkan pariwisata, akan dapat menyerap tenaga kerja lokal dan nasional yang lebih banyak, sehingga pengembangan wisata yang berbasis budaya dan kuliner ini sangat layak untuk dikembangkan. Karena akan dapat menyediakan lapangan kerja yang lebih banyak di daerah, sehingga dapat meningkatkan pendapatan masyarakat secara keseluruhan, disamping juga akan dapat meningkatkan pendapatan pemerintahan.

d. Keberlanjutan aspek lingkungan. Dalam mengembangkan daerah menjadi kawasan pariwisata dengan sarana dan prasarana yang akan dibangunnya nanti perlu melihat struktur tanah yang ada. Melihat kondisi daerah nampaknya memungkinan untuk membangun sarana dan prasarana yang dapat dibuktikan dengan banyaknya sarana yang dibangun sampai saat ini belum ada masalah, sehingga pembangunan sarana dan prasarana yang diusulkan dari aspek lingkungan memenuhi kriteria kelayakan. Tetapi dengan catatan perlu adanya penangangan amdal secara komprehensif.

e. Keberlanjutan sosial yang menjamin peningkatan pembangunan kehidupan masyarakat 
setempat, kompatibel dengan budaya dan nilai-nilai, memelihara dan memperkuat identitas masyarakat (soc-growth) menjadi perhatian sebab pada beberapa daerah terlihat adanya ketidakberlanjutan pariwisata ditinjau dari aspek sosialnya sebagai akibat dari masyarakat lokal yang terbawa pengaruh nilai-nilai yang dibawa wisatawan. Seharusnya tatanan sosial dan budaya lokal mampu menciptakan citra tertentu untuk terus dipertahankan.

f. Keberlanjutan budaya sebagai kekuatan daya tarik wisatawan, budaya sebuah objek wisata tertentu patut ditingkatkan (culgrowth). Seni budaya yang tercipta di masyarakat bisa saja mengalami perubahan. Perubahan ini merupakan dampak negatif yang berlangsung dalam jangka panjang $^{10}$

\section{Investor/Swasta}

Untuk mengembangkan destinasi wisata yang berkelanjutan pemerintah perlu bekerjasama dengan para investor agar dapat memdapatkan perhatiaan serius dari aspek pendaan, agar wisata dapat berkembangan dengan harapan kita bersama. Peran penting saat ini yang harus dilakukan piahak pemerintah daerah adalah mempromosikan destinasi-destinasi wisata yang ada di daerah secara intesif melalu media yang sudah terintegrasi dengan para investor asing, agar dapat di ketahui para invostor asing, sehingga itu bisa menjadi daya tarik tersendiri oleh pihak investor. Saat ini destinasi wisata di Morotai belum tersentuh oleh investor di karena pemerintah daerah tidak melibatkan consultant untuk mela- kukan riset ilmia agar dapat diketataui oleh investor dari aspke keunggualan yang dia milikinya. Artinya para investor perlu mengatau dari hasil riset ilmi, bahwa seberapa besar peluang minat pasar (wisatawan lokal maupun macanara) yang berkunjung ke tempat wisata yang ada di Morotai.

Jikalau para invetor sudah mengatai bahwa destinasi yang ada di Morotai memiliki minat pasar yang begitu tinggi, maka tidak menutup kemugkinan bahwa para invostor akan melakuan invetasi modal terhadap pariwisata yang ada di Morotai.

\section{KESIMPULAN DAN REKOMENDASI}

\section{Kesimpulan}

1. Pariwisata adalah salah satu sektor ungulan meningkatkan perekonomian bangsa, oleh kerana itu pemerintah Kabupaten Pulau Morotai tidak boleh menutup mata persoalan dengan periwisata yang ada di daerah, pemerintah seharusnya menjadi fasilitator dalam pengembangam destinasi pariwisata, karena pariwisata adalah sebua industri baru yang berkembang di era globalisasi saat ini. Peran pemerintah sangat penting dalam mengembangkan destinasi pariwisata yang terdapat di daerah, karena wisata adalah tren gaya hidup di era saat ini kususnya masyarakat mancanegara (turisme).

2. Destina pariwisata yang memjadi tren gaya hidup saat ini para masyarakat mancanagara maupun lokal, hal ini harus menjadi perhatian serius bagi pemerintah indonesia kususnya terhadap pemerintah daerah yang memiliki hak penuh untuk mengem-bangkan kearifan lokal dalam hal ini adalah potensi-potensi wisata, destinasi 
wisata, jikalau dikelola dan dikembangkan dengan baik oleh pihak pemerintah maka daerah tersebut akan mendapatkan peningkatkan pertumbuhan ekonomi dearah secara signifikan.

3. Untuk pengembangan destinasi pariwisata pemerintah harus bekerja sama dengan para invetor dan consultant, selain investor dan consultant, pemerintah juga harus melibatkan masyarakat lokal sebagai tuan rumah yang di bekali dengan kreatifitas mereka masing-masing. Seperti halnya masyarakat lokal dapat mennyiapkan kuliner agar wisatawan yang datang merkunjunng dapat menikmati kuliner tersebut, selain kuliner masyarakat juga menyiapkan sofenir has lokal agar para wisatawan yang dapat berkunjung di suatu tempat destinasi wisata dapat membeli sofenir yang sudah di siapkan oleh masyarakat.

4. Kita menyadari betul bahwa potensi pariwisata kita sangat luar bisa oleh karena itu kiranya ada pihak ketiga (Consultant dan Investor) yang dapat bekerja sama dengan pemeritah daerah untuk mengembangkan pariwisata kita yanga ada di daerah.di sisi lain kita juga sadar bahwa kompoten kita masi terbatas baik secara kuntitas maupun secara kualitas, oleh kerana itu harus ada solusi mislanya bermitrah dengan pihak lain yang teruji dalam memmbantu mengembangkan sumber daya alam kita sebagai salah satu kawasan ekonomi dalam bidang pariwisata. Bagi kita para ilmuan berada di yogyakarta harus dapat mendorong pemerinntah daerah mempercepat proses pembanguna kepariwisataan yang ada di daerah kita.

\section{Rekomendasi}

Dari uraian di atas terlihat bahwa Kabupaten Pulau Morotai memeliki banyak potesi di sektor pariwisata dan karenanya tidak berlebihan kalau Pemerintah pusat menjadiakan Morotai sebagai salah satu kawasan ekonomi khusus (KEK) termasuk dalam bidang pariwisata oleh karena itu penulis merekomendasikan beberapa hal ini terhadap Perintah Kabupaten Pulau Morotai di antaranya adalah sebagai berikut:

1. Komitmen, motivasi, pendanaan dan aksi pemerintah baik dalam regulator dan fasilitator dalam pengembangan pariwisata Kabupaten Pulau Morotai

2. Pengusaha dalam bentuk penyediaan investasi dalam rangka untuk meningkat berbagai usaha di bidang pariwisata Kabupaten Pulau Morotai.

3. Masyarakat atau tuan rumah ikut berpartisipasi aktif dalam pengelolaan dan pelayanan pariwisata.

4. Karena keterbatasan SDM yang di meliki oleh Pemerintah (SKPD terkait), maka perlu melibatkan Consultant Periwisata yang benarbenar profesonsl agar pengembangan pariwisata tersebut dapat memberikan nilai tambah bagi Masyarakat Morotai.

\section{DAFTAR PUSTAKA}

Agung dan Susanto. 2015. Pengembangan Pariwisata Kawasan Kintamani, Jurusan Pariwisata Politeknik Negeri Bali, Kampus Bukit Jimbaran Bali, Soshum jurnal sosial dan humaniora. 5/2/5. 
Ali Hasan 2015. Turism marketing. Yogyakarta: Center for Akademic Publishing Cervice. . 2015. Green Turism Marketing. Julnal media wisata. 13/2/.pp 322342

2016. One Villlage One Destination. Jurnal riset daerah. Badan Perencanaan dan Pembangunan Daerah. Kabupten Bantul.15/1.hlm 1-16

Cut Ermiati danTeridah Sembiring, 2013. Pengaruh Fasilitas Dan Pengembangan Sumber Daya Manusia Terhadap Produktivitas Kerja Karyawan (Studi Kasus PTPN II Kebun Sampali Medan), jurnal Darma Agung. 3/6/ pp.15

Deddy P. Maha Rani. 2014. Pengembangan Potensi Pariwisata, Kabupaten Sumenep Madura Jawa Timur, (Studi Kasus: Pantai Lombang) junal politik muda. 3/3 8-10., pp 412- 421

Fandi Hi. Latief. 2014. Kinerja Pembangunan Sektor Pariwisata (Study pada Dinas Pariwisata dan Kebudayaan Kabupaten Pulau Morotai Tahun 2013) Propinsi Maluku Utara. Journal Of Governance And Public Policy. 1/1/4: pp 1-26

I Putu Anom, 2013. Potensi Kepariwisataan Provinsi Nusa Tenggara Timur (Studi Kasus Di Kawasan Pariwisata Komodo) Dosen Fakultas Pariwisata Unud, Analisis jurnal. 13/1/,pp 113

K. Eni Marhaeni. jurnal,. 2013. Dampak Pariwisata Terhadap Aktivitas
Ekonomi Masyarakat Bali (Perspektif: Ketimpangan Distribusi Hasil Pariwisata) Staf Pengajar Jurusan Administrasi Niaga Politeknik Negeri Bali, jurnal Bisnis dan kewirausahaan. 9/3.11.

M. Heny U. Dewi, C. Fandeli Dan M. Baiquni. 2013. Pengembangan Desa Wisata Berbasis Partisipasi Masyarakat Lokal di Desa Wisata Jatiluwih Tabanan, Bali, kawaistara jurnal. 3/2,8. pp.129-139 